\title{
THE IMPACT OF POLITICS ON HERITAGE AND CULTURAL TOURISM IN SOUTH AFRICA
}

\author{
Jackie Grobler \\ Department of Historical and Heritage Studies, University of Pretoria, \\ Pretoria 0002
}

\begin{abstract}
"A nation without a past is a lost nation. And people without a past are a people without a soul." - Sir Seretse Khama of Botswana. ${ }^{1}$
\end{abstract}

\section{Die impak van politiek op erfenis- en kultuurtoerisme in Suid-Afrika}

Hierdie artikel handel oor die verpolitisering van gedenktekens, monumente, museums en historiese terreine wat as toeristebesienswaardighede dien. Dit bevat eerstens ' $\mathrm{n}$ uiteensetting van die wisselwerking tussen kultuur, erfenis, toerisme en politiek en tweedens ' $n$ ontleding van die konsep ontstaansmite en hoe dit toerisme in SuidAfrika sowel voor as na 1994 beïnvloed het. Derdens volg 'n uiteensetting van die aanbieding van Suid-Afrika se kultuurbesit aan toeriste. Die argument wat aangevoer word is dat die gesamentlike kragte van die ontstaansmite en politieke korrektheid dit feitlik onafwendbaar maak dat politiek ' $n$ bepalende invloed sal uitoefen op die wyse waarop erfenis- en kultuurbesienswaardighede hulle boodskap aan toeriste uitdra. Die situasie in Suid-Afrika voor 1994 word met die huidige stand van sake vergelyk en die gevolgtrekking wat gemaak word, is dat hoewel toerisme tans te midde van die afwesigheid van politieke onstabliteit veel gemakliker funksioneer, politiek voor en na daardie bekende datum 'n massiewe impak op toerisme gehad het.

Sleutelwoorde: ontstaansmite, kultuurbesit, politieke korrektheid, toerisme, erfenis.

This article is about the politicisation of memorials, monuments, museums and historical sites that serve as tourist attractions. Firstly it includes an analysis of the interplay between culture, heritage, tourism and politics, secondly an analysis of the concept foundation myth and its impact on tourism in South Africa both before and after 1994 and thirdly an analysis of the presentation of South Africa's cultural property

S. Moloto, Limpopo Premier, Address on Heritage Day at the unveiling of Kgoshi Malebogo Statue, Ben Seraki Sport Centre, 2006-09-24, http://www.info.gov.za/speeches/2006/ 06092611451001.htm, accessed 2007-04-21. 
to tourists. The argument advanced is that the twin forces of the foundation myth and political correctness make it almost unavoidable that politics will determine the way in which cultural and heritage attractions convey their message. The position in South Africa before 1994 is compared with the present state of affairs and the conclusion is reached that even though tourism operates more easily at present in the absence of political instability, politics has had a massive impact both before and since that well-known date.

Key words: foundation myth, political correctness, cultural property, tourism, heritage.

\section{Introduction}

In the past decade tourism has become a major industry in South Africa. In 2006 more than eight million foreign tourists visited South Africa. About fourteen million domestic tourists undertook trips in South Africa in $2005 .{ }^{2}$ Experts on tourism generally agree that heritage and cultural tourism is probably the fastest growing field within the business as a whole. In South Africa, as in other countries, heritage and cultural tourism is an industry that is closely linked to the nation's past. This past is in many respects turbulent and characterised by intergroup contests for supremacy, military conflict, economic exploitation and cultural suppression. All these factors together make for the politicization of the past and tempts one to conclude that it is unavoidable for politics to have an impact on South Africa's heritage and culture. The primary objective of the article is to test the validity of that assumption.

A quick overview of general trends in world history over many millenia points to the need for peoples and communities to identify their origins. ${ }^{3}$ This is what is referred to as the foundation myth of communities. The monuments and memorials of a country often reflect both the foundation myth and the political ideology of the rulers of that country. It also reflects the way in which a country or people wants to present itself to tourists. A second objective of this article is to investigate the fluid nature of South Africa's foundation myth and how this has impacted on heritage and cultural tourism in (and to) the country.

2 M. van Schalkwyk, Minister of Environmental Affairs and Tourism during the Tourism Month media launch at the Nelson Mandela Museum, Qunu, Eastern Cape, 2007-08-21, http://www.info.gov.za/speeches/2007/07082111151001.htm, accessed 2007-08-30.

3 See e.g. F.M. Heichelheim, C.A. Yeo \& A. Ward, History of the Roman people (Englewood Cliffs, 1984), p. 24; J.R. Green, A short history of the English people (London, 1909), pp. 119120; and L.M. Thompson, The political mythology of Apartheid (New Haven, 1985), p. 4. 
A third issue that is discussed is the impact of the government on the way heritage and culture is presented to tourists. This can vary from direct government interference to more subtle ways of influencing presentations, for example in museums and in the funding of heritage projects. This can be called the manipulation of the cultural property of the country, which refers to the totality of its archaeological, paleantological, natural, historical, religious and unique natural treasure. ${ }^{4}$ It can be assumed that over the years major changes have taken place in the relative importance that ruling politicians in South Africa have attached to some of the elements that make up the country's cultural property, and how this has been presented to domestic visitors and foreign tourists alike. This assumption will be tested in the course of the article.

In the recent past a growing number of researchers have written on aspects of this topic. This includes, on an international level, books by Colin Hall ${ }^{5}$, Melanie Smith $^{6}$ and Joan Henderson. ${ }^{7}$ In South Africa itself a number of noteworthy articles highligthing aspects of the politicization of heritage and cultural tourism have appeared in the past few years. Noteworthy authors of such studies include Albert Grundlingh, ${ }^{8}$ Sabine Marschall, ${ }^{9}$ Harriet Deacon, ${ }^{10}$ Patricia Davison, ${ }^{11}$ Ciraj Rassool and Leslie Witz, ${ }^{12}$ among others. Their findings are extensively used in the present article. It aims to contribute to this lively discourse by highlighting issues such as the interplay between culture, heritage, tourism and politics, the foundation myth and its representation to tourists, the cultural property of South Africa and its presentation to tourists. This should enhance understanding of the complex nature of heritage and cultural tourism.

4 M. Jordaan \& L. Barnard, Omstredenheid oor die ontwikkeling van kulturele erfenistoerisme: die diskoers gedurende die afgelope twee dekades, Joernaal vir Eietydse Geskiedenis 31(2), 2006, p. 205.

5 C.M. Hall, Tourism and politics, policy, power and place (Chichester, 1994).

6 M.K. Smith, Issues in cultural tourism studies (London, 2003).

7 J.C. Henderson, Tourism crises: causes, consequences and management (Amsterdam, 2007).

8 A. Grundlingh, A cultural conundrum? Old monuments and new regimes: The Voortrekker Monument as symbol of Afrikaner power in a post-apartheid South Africa, Radical History Review 81, 2001, pp. 94-112.

9 S. Marschall, Gestures of compensation: post-apartheid monuments and memorials, Transformation 55, 2004, pp. 78-95; S. Marschall, Forging national identity: institutionalizing foundation myths through monuments, South African Journal of Cultural History 19(1), June 2005.

10 H. Deacon, Remembering tragedy, constructing modernity: Robben Island as a national monument, in S. Nuttall \& C. Coetzee, (eds), Negotiating the past : the making of memory in South Africa (Cape Town, 1998), pp. 161-179.

11 P. Davison, Museums and the reshaping of memory, in S. Nuttall, \& C. Coetzee, (eds), Negotiating the past, pp. 143-160. 


\section{The interplay between culture, heritage, tourism and politics}

Smith believes that culture can, in the postmodern world in which we live, be defined as almost any activity that relates to the lives and lifestyles of people. It can simply be regarded as the whole way of life of a people. In the context of tourism culture becomes a commodity that can be packaged and sold much like any other product. On the other hand, each community, nation or people has its own, unique culture which identifies that specific group. It is therefore necessary to distinguish between culture as commodity and culture as identity. Identities are often constructed around ideology. For that reason it cannot be divorced from politics. Moreover, in the postmodern world of mass tourism identities are also products that are manufactured, packaged and marketed like other products. ${ }^{13}$

Another important characteristic of cultures is that they constantly interact with other cultures and are affected by economic, political and social factors. Especially if culture is understood as the values, worldviews and identities that people construct for themselves, it cannot but be politicised. And if culture is politicised, Smith concludes, so is cultural tourism. ${ }^{14}$

As the brilliant, albeit controversial, philosopher-geographer David Lowenthal points out, heritage is a multi-faceted, powerful concept. ${ }^{15}$ For the purposes of this article it is accepted that heritage consists of both tangible and intangible items that are considered valuable (eg. landscapes and musical treasures), are handed down from the past and are taken up by the present generation. Those items are sometimes exploited as a resource, inter alia for tourism. Indeed, the total history of a country becomes a resource in heritage and cultural tourism. Decisions on what specific aspects of heritage should be commodified for tourism, or which section of the nation's heritage in a multi-cultural country like South Africa, often become politicised. Since heritage is concerned with decisions and interpretations, it readily becomes, as Smith warns, "something of a political and ethical minefield." ${ }^{16}$ It can easily happen in a multi-cultural nation that one or more of the communities can be marginalised and that their heritage can be displaced or destroyed. Since South Africa is a multi-ethnic and multi-cultural country, which is marketed for international tourists as "the world

\footnotetext{
12 L. Witz, C. Rassool \& G. Minkley, Repackaging the past for South African tourism, Daedalus 130(1), 2001, pp. 277-296.

13 M.K. Smith, Issues in Cultural Tourism Studies, pp. 11-12.

14 M.K. Smith, Issues in Cultural Tourism Studies, p. 12.

15 D. Lowenthal, The heritage crusade and the spoils of history (Cambridge, 1998), pp. xiiixvii, 1-30.

16 M.K. Smith, Issues in Cultural Tourism Studies, p. 37.
} 
in one country," ${ }^{17}$ it is more or less unavoidable that politics will have an influence on its heritage tourism.

The philosopher A. de Benoist writes that politics is a fundamental part of human existence of which the role is "to organise communities by holding them together." ${ }^{18} \mathrm{He}$ describes humans as socio-cultural beings with contradicting aspirations which are always undetermined. The way in which a community - especially such a diverse community as the South African nation - thinks about its heritage and culture is probably always filled with contradicting aspirations. This will also be true about the way in which heritage and cultural sights are interpreted, amongst others to tourists who visit those sights or read about them. De Benoist points out that politics as a field consists of a framework of decision-making agents with varying viewpoints and aspirations. ${ }^{19}$ This would certainly be the case in the tourism business. Contradictory political views consequently cannot but make their way into the tourism industry.

Colin Hall points out that the relationship between politics and tourism is not primarily concerned with political parties and their influence on tourism policy, even though this is an aspect of the politics of tourism. More important is the fact that politics is about power, about who gets what, where, how and why. He identifies five major elements of politics that are relevant in the context of tourism. Firstly it is concerned with the power to make decisions for a collection of people. Secondly it is about ideologies that determine the choices which affect decisions. Thirdly it is about who makes the decisions and how representative they are. Fourthly it is about the processes by which decisions are made. Finally it has to do with how decisions are implemented and applied to the community. ${ }^{20}$

Another concept that influences the impact of politics on heritage and cultural tourism is the notion of political correctness. The Dutch academic Frans Schouten writes that political correctness "may have started as an honest attempt to undo the existing bias in the historical canon, but in its extreme forms it is best described as twisting the facts to help the truth." ${ }^{21}$ In countries where a large measure of cultural homogeneity is the order of the day, it can be expected that there would seldom be politicised controversy surrounding the interpretation of aspects of the country's

17 International Marketing Council of South Africa, Tourism - the world in one country, South Africa's official gateway - investment, travel, country information, http://www.safrica.info/ , accessed 2007-08-31.

18 A. de Benoist, On politics, Telos 125, Fall 2002, p. 10.

19 A. de Benoist, On politics, pp. 10-11.

20 C.M. Hall, Tourism and politics, policy, power and place, p. 2.

21 F.J. Schouten, Heritage as historical reality, in D.T. Herbert, Heritage, tourism and society (London, 1997), p. 25. 
cultural property in museums or at tourist sights. As already pointed out, the South African nation is everything but culturally homogenic, which opens the door for well-meaning interested parties to manipulate tourist attractions in order to achieve political correctness.

The mere fact that tourism is a massive industry that generates significant economic activity and has the potential to contribute generously towards the Gross Domestic Product (GDP) as well as the economic development and diversification of a country, makes government intervention unavoidable. Any government will want to profit as much as possible from such a lucrative source of income. Tourism can also contribute to nation-building and the articulation of national identities. It can demonstrate the legitimacy of a government to the outside world and thus reinforce government authority. Many governments therefore concentrate on ensuring that especially visiting tourists gain a favourable impression, that heritage and cultural resources are attractively presented, that resources are preserved and that tourists are protected against exploitation and crime. This is often done in partnership with the private sector, but governments are always prepared to play the joint roles of custodians and caretakers. Indeed, it is the duty of governments - and by implication of ruling political parties - to provide the legislative framework within which tourism can operate. In this respect politics and heritage and cultural tourism are inseparable and interwoven. ${ }^{22}$

Political instability and unrest pose a major threat to tourism. There are numerous examples to underline this phenomenon. Tourism to countries like Haiti and Lebanon is almost continuously negatively affected by political unrest. ${ }^{23}$ The civil war in the former Republic of Yugoslavia in the 1990s led to a decline of almost $80 \%$ in tourism to specifically Croatia, one of the states that emerged when Yugoslavia disintegrated. Zimbabwe has similarly experienced a serious decline in tourism in recent years as political instability increased. ${ }^{24}$

\section{The foundation myth and its representation to tourists}

\section{The nature of foundation myths}

Human beings often feel the need to know where they originated from, why they are who they are, what difference their life on earth makes and where they are on their way to. ${ }^{25}$ The same seems to be true about communities and states. In the absence of

\footnotetext{
22 J.C. Henderson, Tourism crises: causes, consequences and management, pp. 34-35.

23 J.C. Henderson, Tourism crises: causes, consequences and management, p. 41.

24 B. Lubbe, Tourism management in Southern Africa (Cape Town, 2003), pp. 63, 147.

25 A.M. Jordaan, Mites rondom Afrikaans (D.Litt.-proefskrif, Universiteit van Pretoria, 2004), p. 3.
} 
concrete evidence communities readily accept mythological histories about their origins as individuals, communities or even nations. Thus the historical books in the Bible identify the patriarchs Abraham, Isaac, Jacob as the founders of the Hebrew nation. The Romans traced their origins back to the Trojan hero Aeneas and his descendants Romulus and Remus. ${ }^{26}$ The English foundation myth centres around the legendary King Arthur and the Knights of the Round Table. ${ }^{27}$ Even the Americans have a foundation myth, namely that they are a new people, formed by those who migrated to the new world seeking freedom. The American nation was, in terms of this myth, founded in a revolution which was the first war of liberation and this new nation is destined to spread freedom across the North American continent and throughout the world. ${ }^{28}$

In South Africa the issue of the foundation myth is often high on the agenda. In the heydays of white rule the impression was more or less generally created by historians that the foundation of the country was laid by the colonisers who came from Europe. According to that foundation myth there were people in South Africa before the arrival of the Europeans, who became settlers in this new land, but those original inhabitants had achieved virtually nothing worth recording. It was the (white) settler community aided by newcomers from Europe and elsewhere in the Western world who built South Africa up to its position of the most advanced and developed state in Africa, at least south of the Sahara Desert. ${ }^{29}$ Since the settlers played the leading role, they deserved to be commemorated and their story deserved to be told to tourists and especially to visitors from overseas. Many places in South Africa, such as rivers and mountains, were renamed by the settlers and these names became the officially accepted names of those places. It was the settlers who founded most towns and cities in South Africa and as a matter of course, gave names to those towns and cities - in some cases names to commemorate their heroes. The outstanding example is the capital city, Pretoria, founded by Marthinus Pretorius and presumably named after his father Andries Pretorius, who was the hero of the decisive Battle of Blood River in $1838 .{ }^{30}$

26 F.M. Heichelheim, C.A. Yeo \& A. Ward, History of the Roman people, p. 24.

J.R. Green, A short history of the English people, pp. 119-120.

L.M. Thompson, The political mythology of Apartheid, p. 4.

29 S.F.N. Gie, Geskiedenis van Suid-Afrika, of Ons verlede, Deel I - 1795 (Stellenbosch, 1924), Voorwoord; A.J.H. van der Walt, J.A. Wiid en A.L. Geyer, met D.W. Kruger (reds), Geskiedenis van Suid-Afrika (Derde uitgawe, Kaapstad, ca. 1978); C.F.J. Muller, (red), Vyfhonderd jaar Suid-Afrikaanse geskiedenis (Derde uitgawe, Pretoria, 1980), Inleiding; F.A. van Jaarsveld, Van Van Riebeeck tot P.W. Botha. 'n Inleiding tot die geskiedenis van die Republiek van Suid-Afrika (Derde uitgawe, Johannesburg, 1982), pp. 1-17.

30 S.P. Engelbrecht et al. (eds), Pretoria (1855-1955) History of the City of Pretoria published in the Centenary Year 1955 (Pretoria, 1955), pp. 6-8. 
Marschall writes that monuments and memorials are the means of visualising foundation myths. Both the members of the community whose foundation myth is visualised, as well as tourists, have the opportunity to gaze upon the message effused by these monuments and to drink in the message they mean to convey. The monuments moreover 'cast in bronze' or 'carve in stone' the foundation myth for future generations, solidifying the intended message. Especially national monuments which are initiated by the state and are intended to forge a specific national identity can represent key themes of a country's foundation myth. ${ }^{31}$

\section{Afrikaner foundation myths and their representation}

For the Afrikaner people the outstanding representation of their foundation myth is the Voortrekker Monument in Pretoria. According to the historian Albert Grundlingh this monument "serves the foundational myth of exclusive Afrikaner power". ${ }^{32}$ Yale University historian Leonard Thompson is even more specific. To him the key element in the Afrikaner foundation myth is the Taking of the Vow, since it served as the basis of the belief of Afrikaners of the mid 20th century that they were 'God's Chosen People'. ${ }^{33}$ The Taking of the Vow is portrayed on the historical frieze in the Voortrekker Monument in Pretoria as well as in a large memorial in Kroonstad in the Free State [Fig. 1].

The Voortrekker Monument in Pretoria is one of dozens of memorials and statues erected by the Afrikaner community to pay homage to the Voortrekkers of the Great Trek (1835-1840). There can be little doubt that Afrikaners regard the Trek as a key event in the foundation of their 'nation'. The other key event was the Anglo-Boer War of 1899-1902. Both form part of the Afrikaner 'struggle history': the Great Trek being to struggle to achieve freedom and the Anglo-Boer War the struggle to safeguard their freedom. In both struggles relatively large numbers of Afrikaners paid with their lives fighting for their cause, which is a universal cause, namely freedom. Those martyrs are honoured as heroes in Afrikaner memorials, such as the historical frieze in the Voortrekker Monument that portrays women and children being killed by Zulu warriors at Weenen in February 1838, and the National Women's Memorial in

\footnotetext{
S. Marschall, Forging national identity, p 22.

A. Grundlingh, A cultural conundrum?, p. 96.

33 L.M. Thompson, The political mythology of Apartheid, frontispiece and pp. 112-114.
} 


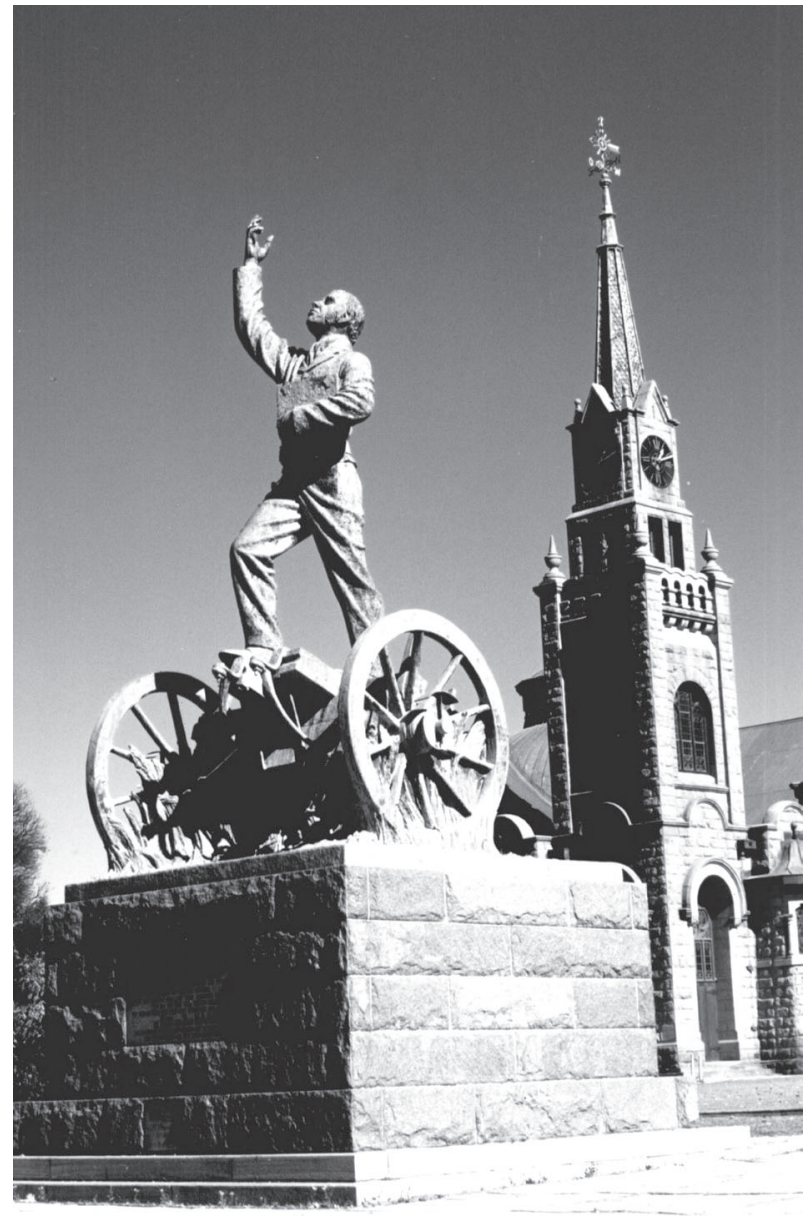

Figure 1: Sarel Cilliers statue, Kroonstad (Photograph: Jackie Grobler) 
Bloemfontein [Fig. 2], which pays homage to the approximately 28000 Afrikaner women and children who died in the Concentration Camps erected by the British military authorities during the Anglo-Boer War. ${ }^{34}$ On the pedestal of the Women's Memorial the inscription reads: To our women heroes and adorable children who gave their lives for our cause. They did not die in vain, it is claimed. They died as a sacrifice to the freedom of those who survived. At the unveiling of this monument in 1913 the last President of the former Republic of the Orange Free State, Marthinus Steyn, declared that he believed that the day would come when every member of the South African nation, whatever his or her origins, would accept the virtues immortalized in the monument as part of their common heritage. ${ }^{35}$

There are, of course, also monuments to Afrikaner men who lost their lives in the Anglo-Boer War. These were called Burgher monuments and were erected in virtually every district of the former Boer republics as well as in towns in the Cape and Natal, which were British colonies at the time of the Anglo-Boer War, but from which many Afrikaners joined the Boer forces. The message of those monuments was that these men sacrificed their lives for freedom and for justice. ${ }^{36}$ The vast majority of Afrikaners still refer to the War of 1899-1902 as either the Anglo-Boer War or Die Tweede Vryheidsoorlog - The Second War for Freedom, to distinguish it from Die Eerste Vryheidsoorlog - The First War for Freedom (Anglo-Transvaal War), fought by the Transvaal Republic against the British in 1880-81. The refusal of all but a handful of Afrikaners to accept the politically correct name South African War for the conflict of 1899-1902, and the preference for one of the other two names by leading Afrikaans scholars of the war, such as Fransjohan Pretorius ${ }^{37}$, underline that for most Afrikaners the war was in the first place the culmination of their ancestors' military struggle for freedom against the British Empire.

The way in which some major events in South African history took place and the impact that those events had on generations which followed go some way to explain the difficulty in bringing about a single, united foundation myth for all South Africa's communities. The historian Bill Nasson argued in an article published in 2000 that the Anglo-Boer War (1899-1902) had a decisive impact on the formation of

34 M.J. Swart et al., Afrikanerbakens (Johannesburg, 1989), pp. 102 \& 170-172; J. Grobler, Ontdek die Voortrekkermonument/Discover the Voortrekker Monument (Pretoria, 2001).

35 Dr Okulis, Die Boervrouw. Moeder van haar volk (Bloemfontein, 1918), p. 153.

36 E.g. the Burgher Monument in Standerton, Mpumalanga, on which the inscription reads (translated into English): This Monument is erected by relatives and friends to honor fallen burghers and women and children of Standerton who passed away for liberty and justice in the Three Years War 1899-1902. Visited by author 2006-09-19.

37 F. Pretorius, Kommandolewe tydens die Anglo-Boereoorlog 1899-1902 (Kaapstad, 1999). 


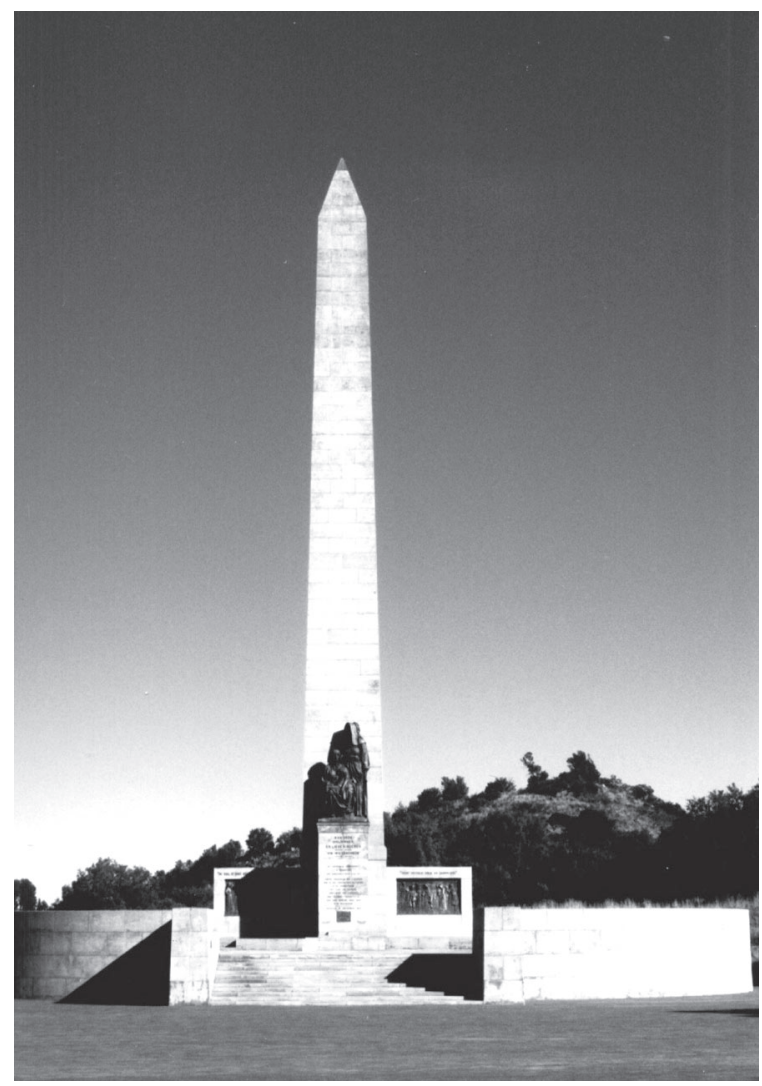

Figure 2: National Women's Memorial, Bloemfontein (Photograph: Jackie Grobler)

rigid Afrikaner nationalist identity for the total duration of the 20th century. At the same time for the post-1912 South African Natives National Congress, which later became the African National Congress, the war was of no major consequence since it was regarded as a colonial squabble over who of the Afrikaners or the English would be top dog and be able to exploit the land and labour of the conquered black majority. ${ }^{38}$

38 B. Nasson, Commemorating the Anglo-Boer War in the post-Apartheid South Africa, Radical History Review 78, 2000, p. 150. 


\section{Foundation myths of the 'new' South Africa}

The perception that their history consisted of struggle against injustice and for freedom was firmly entrenched in the Afrikaner foundation myth for most of the twentieth century - despite criticism that the apartheid policy was inherently unjust and 'a crime against humanity'. ${ }^{39}$ In a cruel twist of irony a very similar perception, namely that their history also consisted of a struggle against injustice and for freedom, was similarly entrenched in the foundation myth of the founders of the 'new' South Africa in the 1990s. Thus when the new government took over in 1994 - a mainly black government dominated by the African National Congress - the new leadership congratulated themselves, claiming that they had led the struggle to overthrow white supremacy and had brought freedom to the peoples of South Africa. They needed a new foundation myth which would give due credit to black South Africans. As the minister of Arts and Culture, Pallo Jordan, explained to a journalist in 2004: "If you came from Mars and you went on the evidence of what is there in these public spaces [in the line of statues, monuments and memorials], you'd come away with the impression that whites were the original inhabitants [of South Africa] and Africans were the immigrants." 40

Monuments have the power to achieve more than merely strengthening a community's foundation myth. Marschall believes that: "Monuments are a means of asserting group values, restoring dignity and self-esteem, expressing identity and recognising achievement." ${ }^{41}$ Even more important is that monuments to commemorate their own heroes and their own achievements make people feel at home. As Thembinkosi Ngcobo, Executive Director of the eThekwini Department of Parks, Recreation and Culture, told Marschall: "Monuments create a sense of belonging, which de facto many people currently don't enjoy - especially in urban centres strutting with colonial and apartheid-era monuments." 42

Struggle and sacrifice are popular themes around which numerous memorials have been erected since 1994. Thus memorials to commemorate the victims of massacres and political prosecution have been constructed among other places in Soweto, namely the Hector Pieterson Memorial, in Mamelodi east of Pretoria, namely the Solomon Mahlangu Memorial at the Mamelodi Massacre Site, in the former

\footnotetext{
39 According to the General Assembly of the United Nations - see The United Nations and Apartheid (New York, 1994), p. 325.

40 E. Randall, The art of turnabout, Mail \& Guardian (online), 2004-09-10.

41 S. Marschall, Gestures of compensation, p. 80.

42 S. Marschall, Gestures of compensation, p. 81.
} 
Republic of the Ciskei, namely the Bisho Massacre Memorial, in southern Gauteng, namely the Sharpeville Massacre Memorial and in the Eastern Cape, namely the Langa Massacre Memorial in Uitenhage. Of those only the Hector Pieterson Memorial draws large groups of tourists, but the Tshwane Metropolitan Municipality in 2005 identified the Mamelodi Massacre Site as a destination that would in future be increasingly marketed. ${ }^{43}$

In terms of the 'new' South Africa foundation myth the struggle against white oppression and injustice began long before the institution of apartheid. Memorials which tourists can visit and where they can learn of the struggles in previous centuries are regarded as essential. Minister Jordan was quoted by a newspaper as saying: "Of course we have statues of Nelson Mandela in Sandton, Albert Luthuli in Stanger and Steve Biko in East London [among others]." However those were not enough, since they were all of the 20th century and played into the denial and the pre-1994 myth of the empty land. Individuals who earlier on played leading roles in areas such as religion should, according to Jordan, also be commemorated. He specifically mentioned the Reverend John Knox Bokwe and Tiyo Soga, significant black figures in the history of Christianity in South Africa. ${ }^{44}$

One of the most controversial statues that was recently erected in South Africa is that of Tshwane [Fig. 3], a legendary chief, in front of the city hall in Pretoria, close to an equestrian statue of the man after whom Pretoria was named, Andries Pretorius, and of the statue of his son, Marthinus Wessel Pretorius, who was the founder of the original settlement in 1855. Pretoria forms part of the area of the City of Tshwane, which was established in 2000 and was named after the legendary Tshwane. Nobody can with any certainty establish who Tshwane was - not even whether he belonged to a Ndebele- or a Tswana-speaking community. Neither is there any clear evidence on anything that he ever achieved, nor that he actually was a chief or even that he actually existed. ${ }^{45}$ According to oral tradition related at the unveiling of the statue in 2006, Tshwane lived in about 1600 . Towards the end of his life he ordered six of his sons to take their families and move away from what is today the Tshwane area into six different directions. This he did to save his descendants from "genocide by the

43 Z. Ntuli, Siyaya eCity of Tshwane poised to boost local tourism, BUA News Online, 200501-24, Compiled by the Government Communication and Information System, http:// www.buanews.gov.za/view.php?ID=05012415151001\&coll=buanew05, accessed 2007-08-31.

44 E. Randall, The art of turnabout, Mail \& Guardian (online), 2004-09-10.

45 L.J. Louwrens, The origin and meaning of the place name Tshwane, South African Journal of Cultural History 20(1), 2006, pp. 112-113. 
plundering Voortrekkers". ${ }^{46}$ However, the Voortrekkers only emerged in history in the 1830s, when they trekked into the interior of South Africa. Nevertheless the Tshwane Metropolitan Council is adamant to rename Pretoria after Tshwane and indeed consistently refers to the city as Tshwane, even though the name change has not been officially sanctioned by the relevant authorities. The erection of the statue in

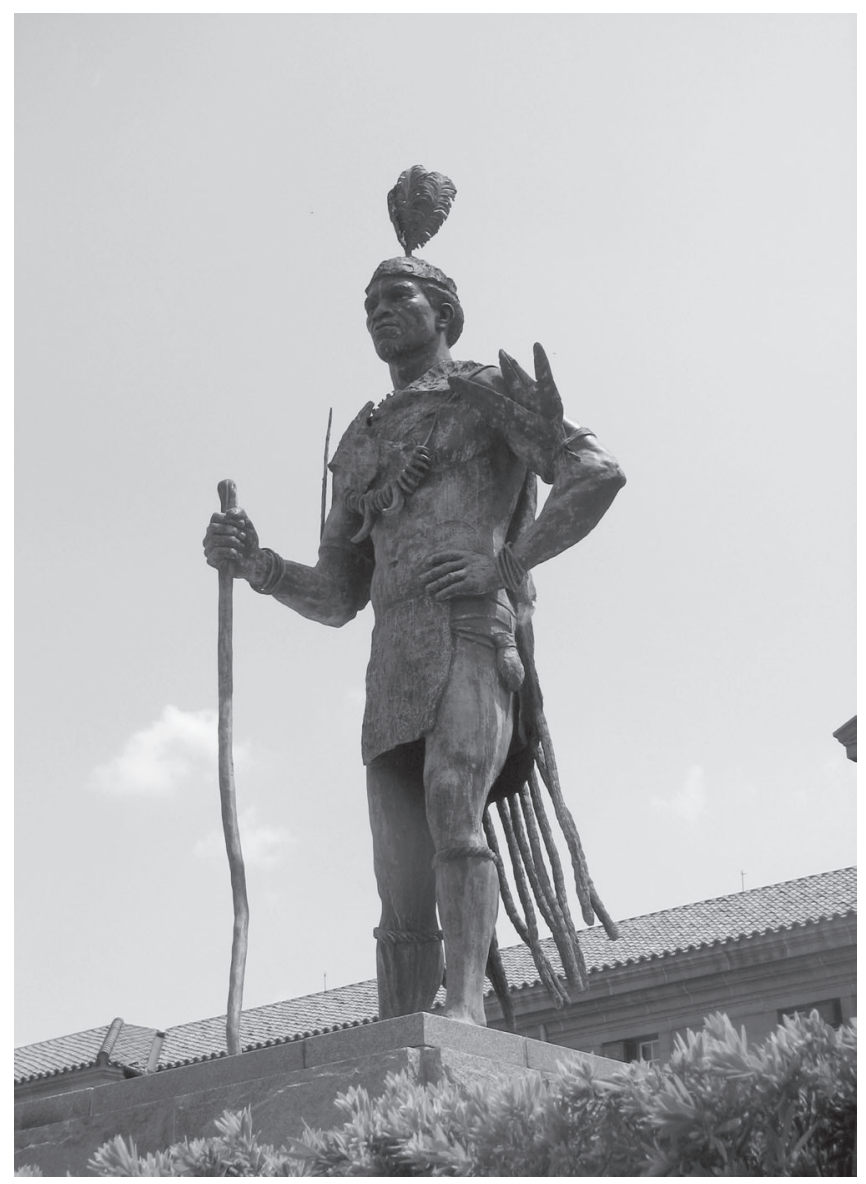

Figure 3: Tshwane statue, Pretoria (Photograph: Jackie Grobler)

46 N. Jackson, Hoofman Tshwane se standbeeld onthul, Beeld, 2006-07-06, http:// www.news24.com/Beeld/Suid-Afrika/0.,3-975 1964109,00.html, accessed 2007-08-30. 
2006 was probably done to give legitimacy to this change. City officials decided to identify the statue with a plaque bearing only the inscription Tshwane, but at the last moment a senior official ordered that the inscription should read Chief Tshwane. The inscription on the base furthermore alleges that it was through his "existence our city origin and history sprung". This was probably inscribed to counter the inscription on the base of the statue of Marthinus Pretorius, which refers to the founding of the city in $1855 .{ }^{47}$ Marschall writes that monuments "create an imagined, desired past, compensating for absences and shortcomings of the real past". ${ }^{48}$ The Tshwane statue is probably the best example in South Africa of the creation of such an imagined past.

The 4,2 metres high bronze statue of in Pretoria corresponds closely to the requirement of black South Africans that new monuments must look 'impressive and dignified.' As Marschall has pointed out, "the current practice is to imitate western commemorative conventions. A 'proper monument' is regarded as a bronze statue on a pedestal, even though this style might be questioned in the post-apartheid context that aims to create an 'African Renaissance'." 49 A remarkably similar statue that was erected in the last decade is that of Kgoshikgolo Sekhukhune I at Tjatje in the Limpopo Province to commemorate that celebrated Pedi leader's steadfast resistance to the incursions of Transvaal Boers and subsequently of the British empire into the lands of his people in the second half of the 19th century. The Limpopo Province also erected statues for two other black chiefs who battled against the forces of colonialism in that same period, namely Makhado of the Venda and Malebogo of the Hanwana. At the unveiling of the latter statue the Premier of Limpopo, Sello Moloto, clearly explained the value of these monuments:

The legacy of this great chief of Bahanwana continues to inspire us even today in our pursuit for justice, freedom and a better life for all. Today, Kgoshi Malebogo's name has become a rallying point and an embodiment of noble anti-colonial battles of the Bahanwana people. Malebogo is counted amongst the many nation-builders of our country such as Nghunghunyane, Shaka, Bhambata, Sekhukhune, Makhado, Mokopane and many others who shed blood for our own liberation... The statue we are unveiling today serves as a token of our appreciation for the role played by him and the Bahanwana

47 Sapa, Plastic comes off Tshwane statue, July 072006 at 12:47AM, http://www.iol.co.za/ index.php?set id=1\&click id=6\&art id=qw1152218884447B232, accessed 2007-04-19. The plaque bearing the inscription has since been removed by unknown people. Visited 2008-0208 .

48 S. Marschall, Gestures of compensation, p. 86.

49 S. Marschall, Gestures of compensation, p. 84. 
people in the liberation of South Africa and Africa in general. The monument we have unveiled today will serve as a heritage site and a source of honour for the people of Limpopo and South Africa in general..$^{50}$

Amongst the great leaders of the past few rank higher in the foundation myth of the new South Africa than the Zulu kings Shaka, uDingane and Cetshwayo (but not Mpande, whose name is seldom mentioned, probably since he 'collaborated' with the Voortrekkers). It is therefore not surprising that on a provincial level the tourism authorities in KwaZulu-Natal market their region as 'The Kingdom of the Zulu', even though the whole present-day province was never incorporated into the historic Zulu Kingdom, and many in the province feel that their own heritage and culture is being marginalised as a result. Especially the significant Indian minority feel this way, since their tradition of pacifism and non-violent resistance as symbolised by Mahatma Ghandhi, who for many years resided in the province, has largely been written out of the 'official' KwaZulu-Natal tourism marketing drive..$^{51}$

Museums are amongst the highest ranked of all destinations for heritage and cultural tourism. In South Africa the political changes since 1994 have had a massive impact on the nature of displays in almost all kinds of South African museums from state controlled to private institutions. This was partly a result of state policy, since the government has given the highest priority to transformation which would ensure that museum displays that supported the foundation myth of the apartheid dispensation are thoroughly revised. ${ }^{52}$

One of the first museums which witnessed massive changes was the South African Museum in Cape Town. Amongst the most controversial displays in this, the oldest museum in the country, was the so-called 'Bushmen Diorama'. Surveys suggested that it was also the most memorable of all the museums' exhibits. However, critics of the display alleged that the 'Bushmen' in the diorama were portrayed as stereotypes of

50 S. Moloto, Limpopo Premier, Address on Heritage Day at the unveiling of Kgoshi Malebogo Statue, Ben Seraki Sport Centre, 2006-09-24, http://www.info.gov.za/speeches/2006/ 06092611451001.htm, accessed 2007-04-21.

51 H. Hughes, What is remembered and what is forgotten: a decade of redefining culture and heritage for tourism in South Africa. Research paper, University of Lincoln, 2000, p. 5.

52 Z.P. Jordan, Arts \& Culture Budget Speech 2004/2005 in National Assembly, Cape Town, 2004-06-23, www.capegateway.gov.za/afr/pubs/speeches/2004/jun/82068, accessed 2008-0407; C. Soudien, How relevant are our museums in the African context? Lecture at Iziko Summer School 2007, www.iziko.org.za/education/pastprogs/pdfs/2007Crain_Soudien.pdf-, accessed 2008-04-07. 
primitive beings, with no history, set in a timeless imagined past. ${ }^{53}$ It was only in 2001 that the diorama was closed and the 'Bushmen' were removed from the tourist gaze according to a spokesperson of the museum because "the Bushmen were being treated like natural history specimens". ${ }^{54}$ This decision did not satisfy all South Africans who regarded themselves as San or Bushmen. It was reported that the National Khoisan Consultative Conference which was held in Oudtshoorn at the time supported the closure, but a group of southern African Bushmen who gathered in Windhoek for a meeting of the San Cultural Heritage Committee, condemned the closure. ${ }^{55}$

Robben Island is one of South Africa's most popular attractions especially for international tourists. Its fame is largely built on its association with former president Nelson Mandela, who spent 18 of the 27 years that he was imprisoned on the Island. The former South African government appointed a committee in the 1980s to discuss proposals to turn the Island into a tourist attraction after the closing of the prison some time in the future. There was even talk of establishing a casino. However nothing came of it and the prison remained operational into the $1990 \mathrm{~s} .{ }^{56}$

Robben Island was eventually developed as a tourist destination mainly for political reasons. Its development was the result of a cabinet decision made in 1996 and it became, according to President Nelson Mandela, the "first major new heritage institution of democratic South Africa" ${ }^{57}$ In this respect it was developed as a symbol of, on the one hand, South Africa's "vicious" apartheid past and on the other hand "the spirit of resilience, resistance, courage and determination" of those who fought for the country's freedom. ${ }^{58}$

The Robben Island Museum (RIM) sets out to educate tourists about South Africa's political past with workshops, tours and camps for children. The ideal is that tourists should learn about modern day South Africa and its embracing of a culture of human rights and respect for ethnic, cultural and religious diversity. ${ }^{59}$ The challenge

53 P. Davison, Museums and the reshaping of memory, pp. 143-160.

54 SAPA, Museum defends closure of 'Bushmen' exhibition, Dispatch Online, 2001-04-06, http://www.dispatch.co.za/2001/04/06/southafrica/MUSEUM.HTM, accessed 2007-08-30.

55 SAPA, Museum defends closure of 'Bushmen' exhibition, Dispatch Online, 2001-04-06, http://www.dispatch.co.za/2001/04/06/southafrica/MUSEUM.HTM, accessed 2007-08-30.

56 H. Deacon, Remembering tragedy, constructing modernity, pp. 168-170.

57 N. Mandela, Address at the opening of the Robben Island Museum on Heritage Day, 24 September 1997, http://www.anc.org.za/ancdocs/history/mandela/1997/sp0924a.html, 200708-27.

58 J. Zuma, Address at the official opening of the University of Western Cape (UWC), Robben Island Mayibuye Archives, 2001-06-13, http://www.info.gov.za/speeches/2001/ 0106141045a1001.htm, accessed 2007-08-27.

59 International Marketing Council of South Africa, Robben Island remembers, 2005-07-14, http://www.southafrica.info/ess_info/sa_glance/history/robbenisland.htm, accessed 2007-0827. 
for RIM will be to avoid the pitfalls of political correctness, which would mean simply telling the history in a way that will please the political leaders of the new South Africa by twisting the "facts" to help the "politically correct" truth. The pitfall deepens as a result of the fact that former prisoners are in many cases used as guides at the RIM. The result is that different narratives are told to tourists about the anti-apartheid struggle and its goals, "depending on which of the once-outlawed political parties the guide belonged to". ${ }^{60}$

\section{The cultural property of South Africa and its presentation to tourists}

Jordaan and Barnard point out that the World Bank regards the cultural property of a country as the totality of both its tangible and intangible culture and its historical and natural heritage. ${ }^{61}$ The South African Department of Environmental Affairs and Tourism concurred by stating in the White Paper on the Development and Promotion of Tourism in South Africa in 1996 that: "The cultural environment includes much more than museums and unique archaeological sites. It also includes mission settlements, sites of slave occupation, urban space used for ritual purposes, rock art sites, rock formations and natural landscapes which have national and international cultural significance." ${ }^{2}$

South Africa is home to eight World Heritage Sites designated as such by the United Nations Educational, Scientific and Cultural Organisation (UNESCO). Those eight include Robben Island, which has already been discussed in this article, the Fossil Hominid Sites around Sterkfontein in Gauteng, which is marketed for tourism as the Cradle of Humankind, and Mapungubwe in the Limpopo Province. President Thabo Mbeki claimed in 2000, in a speech opening the South African Pavilion at the World Expo in Hannover, Germany, that Sterkfontein was "the first dwelling place of humankind, that this is the cradle from which all humanity began." ${ }^{63}$ At the opening of the multi-million Rand visitors centre at Sterkfontein, named Maropeng, Mbeki repeated in 2005 that "we can now boldly proclaim that the African continent is the

\footnotetext{
60 H. Hughes, What is remembered and what is forgotten, p. 2.

${ }_{61}$ M. Jordaan \& L. Barnard, Omstredenheid oor die ontwikkeling van kulturele erfenistoerisme, p. 206.

62 Government of South Africa, Department of Environmental Affairs and Tourism, White Paper: The development and promotion of tourism in South Africa, May 1996, paragraph 5.7. Downloaded from http://www.polity.org.za/govdocs/white_papers/ on 1999-01-26.

63 T. Mbeki, Address by President Thabo Mbeki of South Africa at the opening of the South African Pavilion at Expo 2000, Hannover, 2000-06-02, http://www.info.gov.za/speeches/ 2000/000602355p1001.htm, accessed 2007-08-30.
} 
cradle of humanity". ${ }^{64}$ Mbeki could state this claim with confidence, since it was based on sound archaeological evidence. Turning to Mapungubwe, Sello Moloto, the Premier of the Limpopo Province, told a tourism summit in 2004 that: "The great Mapungubwe is recorded in history as one of the flourishing Iron Age Metropol, [sic] which traded in gold, ivory and animal skin in the whole of Africa and the far flung nations of the east including the Chinese, Indians and Arabs in the middle-east. This happened long before Africa was conquered and colonised." ${ }^{65} \mathrm{He}$ was obviously 'twisting the facts to help the truth' of political correctness. To use sound archaeological evidence as authority again: the society at Mapungubwe that had trade links stretching to the east coast of Africa seems to have inhabitated that terrain for less than a century (about 1220-1300). ${ }^{66}$ There is absolutely no evidence that they had direct links with any society outside Africa.

In addition to World Heritage Sites in South Africa, cultural villages are very prominent forms of politically-correct tourism destinations in South Africa. These attractions are being established all over the country. They are quite popular with some international tourists - but not all, since two-thirds of foreign tourists to South Africa are from other parts of Africa and are not normally customers of cultural villages. There seems to be general consensus that small entrepreneurs and local communities are enabled to profit from tourism by becoming involved in cultural villages. This is only true to a limited extent since, in fact, all the most successful cultural villages - including Lesedi near the Gauteng metropoles and Shakaland in KwaZulu-Natal - belong to nationwide hotel groups. They pocket the profits, while the employees at cultural villages complain that they have to perform like professional tribe members in reconstructed traditional homesteads while not earning enough money to move out of the mud and zinc shacks in which they live. ${ }^{67}$

A significant phenomenon of a related kind is that leading spokespersons of the government condemn the pre-1994 authorities for museum displays that presented black culture as static, but at the same time applauds the establishment of cultural villages, which has as a main motive the display of traditional black culture in its original (=static) form. Another irony in the present-day search for political correctness

64 T. Mbeki, Address at the opening of the Maropeng Visitor Centre, 2005-12-07, http:// www.polity.org.za/article.php?a_id=78820, accessed 2007-08-30.

65 S. Moloto, Welcome address by Mr Sello Moloto, Premier of Limpopo, during the Tourism Summit at The Ranch Hotel, Polokwane, 2004-09-07, http://www.info.gov.za/speeches/ 2004/04090710151003.htm, accessed 2007-08-30.

66 A. Meyer, The archaeological sites of Greefswald. Stratigraphy and chronology of the sites and a history of investigations (Pretoria, 1998), pp. 261-265.

$67 \mathrm{H}$. Hughes, What is remembered and what is forgotten, pp. 4-5. 
is that the concept tribe, which was in the struggle years often condemned as a construction of white oppressors, is legitimised by the rise of cultural villages that celebrate ethnic culture. Thus 're-constructed' tribes have become one of the main tourist attractions in the new South Africa and tribalism seems to be acceptable again. ${ }^{68}$

A closely related politically correct development is township tours. This is in many instances becoming a genuine community-based tourism initiative, since while on township tours, visitors are likely to encounter the reality of actual township life. On a typical township tour, visitors will visit one or more places of historical interest - often associated with the anti-apartheid struggle, a church or a welfare facility where they can make donations, a shebeen where they can buy food and/or drinks, and a cultural display. The irony of township tours is that they contribute to what critics call the 'ghettoising' of suburbs in the new South Africa since they perpetuate the spatial division on ethnic lines that was central to the apartheid policy. ${ }^{69}$

One of the primary township tourism destinations of international visitors to South Africa as well as of local tourists is Soweto, the vast residential area southwest of the centre of Johannesburg. Numerous historical sights in Soweto associated with the anti-apartheid struggle are daily visited by large numbers of tourists. The township still carries the scars of the anti-apartheid struggles that dominated its life in the 1970s and 1980s. Amos Masondo, the Mayor of Johannesburg, claimed in 2006 that 250000 local and foreign tourists visit the township each year. He added that "Soweto is the most visited township in South Africa ... Its heritage and history, its culture and unique position in the liberation struggle, make it a must-see destination for foreign as well as local visitors." ${ }^{70}$

Numerous museum displays in South Africa in addition to those in the South African Museum in Cape Town that were discussed earlier on in the article, have been significantly changed since 1994. An outstanding example that also comes from Cape Town is the Old Slave Lodge which recalls the history of slavery in South Africa. The museum is housed in the building which was actually used as a slave lodge by the Dutch East India Company before 1795, but was later used for other purposes, of which the last was to house the South African Cultural History Museum. ${ }^{71}$

\footnotetext{
$68 \mathrm{H}$. Hughes, What is remembered and what is forgotten, p. 6.

69 H. Hughes, What is remembered and what is forgotten, p. 7.

70 L. Sindane, Soweto tourist info centre opens, South Africa Info, 2006-02-23, http:// www.southafrica.info/plan_trip/holiday/cities/soweto-230206.htm, accessed 2007-08-26.

71 H. Fransen, A guide to the old buildings of the Cape. A survey of extant architecture from before c 1910 in the area of Cape Town - Calvinia - Colesberg - Uitenhage (Johannesburg, 2004), pp. 31-32.
} 
In this museum the emphasis was on the cultural history of white rather than slave South Africans. Transformation of exhibits to represent the legacy of slavery took place in numerous other museums in the Cape as well. ${ }^{72}$

One of the most successful transformations in museum displays in South Africa occurred at the National Military Museum in Johannesburg. The exhibits in this museum used to represent the military might of the white South Africans only, including weaponry used to 'fight the terrorists' (meaning the armed forces of the banned ANC and PAC in the 1960s - 1980s). However, after the introduction of recent changes, the museum now not only recognises the role of black soldiers in South Africa's pre-1994 military history, but has added new exhibitions displaying the guerrilla campaigns waged by the ANC and PAC during the struggle years culminating in the negotiated settlement in 1992-93. This was done without significantly dismantling the old exhibitions, in other words, by means of "extension rather than revision." 73

In addition to museums, some monuments also went through a process of transformation since 1994. This includes the Voortrekker Monument in Pretoria, which actively remolded its symbolism in an attempt to rid itself of its image of representing the 'holy ground' of aggressive Afrikaner nationalism. This monument receives a small state grant annually, but its considerable running cost and upkeep is financed by visitors, of whom the majority are foreign tourists. Grundlingh remarked in 2001 that the monument had lost its position as the holy shrine of Afrikaner nationalism. He furthermore observed that the Monument was leaving the field of contested history and predicted that it would soon become mere heritage - a product fit for tourist consumption only ${ }^{74}$ It probably was a hasty prediction, since the Monument is fast becoming the centre around which the conservation of Afrikaner historical sites across the whole of South Africa revolves. Furthermore the first phase of a R10 million Afrikaner Heritage Centre is currently under construction on the terrain of the Monument. ${ }^{75}$

Even though Freedom Park in Pretoria is not yet open for tourists, no discussion of heritage and cultural tourism in South Africa would be complete if it ignores this huge monument which is at present under construction. The government wants, in the words of President Mbeki, this to be a memorial "that will honour and celebrate

72 K. Ward \& N. Worden, Commemorating, suppressing, and invoking Cape slavery, in S. Nuttall, \& C. Coetzee, (eds), Negotiating the past, pp. 201-220.

$73 \mathrm{H}$. Hughes, What is remembered and what is forgotten, p. 3.

74 A. Grundlingh, A cultural conundrum?, pp. 101, 109.

75 Personal communication to the author by G.N. Opperman, CEO of the Heritage Foundation, 2007-11-16. 
the heroes and heroines who sacrificed so that we could achieve political emancipation." 76 Those heroes were not only South Africans, but some came from other countries. The issue of whose names should be included on the monument and whose names should be left out has generated emotional debates and public accusations. It is not intended to discuss those issues in this article. Of more importance is situating Freedom Park in the total context of commemoration in South Africa. In 1998 the Truth and Reconciliation Commission recommended that in addition to monetary reparations for victims of apartheid, there should be symbolic reparations like memorial gardens and reburials. So far the government has, according to Marschall, been very active in its delivery of symbolic reparations in the form of monuments and memorials, but much slower in payments to victims and their families. Marschall comments that one might ask why the government prefers to spend over R300 million in the development of Freedom Park, rather than allocate those funds to reparation payments to victims of apartheid. "The reason is that Freedom Park and other monuments of its kind fulfil an important role in legitimating the current sociopolitical order." 77

\section{Evaluating the impact of politics on heritage and cultural tourism in South Africa}

The impact of politics on heritage and cultural tourism needs to be evaluated on different levels, depending on the measures used. Purely from a tourism as business perspective the political changes that took place in South Africa certainly had a huge positive impact on tourism. Not only has the number of tourists to this country increased substantially, but a number of prominent new attractions for those tourists have been or are being developed, as indicated in this article. South Africa indeed gives to the world one of the most outstanding examples of the positive impact that politics can have, namely the tourism generated by Nelson Mandela. Since his release from prison in 1990 Mandela became a political icon with unequalled stature both nationally and internationally. Tens of thousands of tourists are annually drawn to sights in South Africa that are specifically linked to this remarkable individual.

On the negative side it is equally clear that trustworthy portrayals of South Africa's heritage and culture at tourist attractions are facing the danger of being underploughed by the current emphasis on political correctness and transformation.

\footnotetext{
76 T. Mbeki, Address at the occasion of the launch of Freedom Park, Pretoria, 2002-06-16, http://www.info.gov.za/speeches/2002/02061809461004.htm, accessed 2007-08-30.

77 S. Marschall, Gestures of compensation, pp. 84-86.
} 
Some might argue that this is unavoidable - that the portrayal of the past in monuments, statues and memorials in all parts of the world is more or less one-sided. The foundation myth of those groups who are in political control demand portrayals supporting their legitimacy. The major political change that occurred in this country in 1994 makes it possible to compare the portrayal of the past in two distinct periods in South African history. In both cases there is/was little sympathy with the cultural heritage of "the other side", even though both sides interpreted their history as a struggle for freedom. One cannot but conclude that it seems to have been before 1994 and to still be after that date close to impossible for those in political control of South Africa to acknowledge the heritage, historical pride and nostalgic memories of communities who are not prepared to concede cultural submission to those who rule. 